International Journal of Linguistics, Literature and Translation

ISSN: 2617-0299 (Online); ISSN: 2708-0099 (Print)

DOI: 10.32996/ijltt

Journal Homepage: www.al-kindipublisher.com/index.php/ijltt

IJLLT

\title{
The Construction of U.S. Armed Forces' Image Through Translation Activities in Hollywood Blockbusters
}

\author{
Liang Liqiao \\ Postgraduate student of Graduate Institute of Interpretation and Translation (GIIT), Shanghai International Studies University, \\ Shanghai, China
}

$\square$ Corresponding Author: Liang Liqiao, E-mail: 68560948@qq.com

\begin{abstract}
ARTICLE INFORMATION
Received: 15 September 2021

Accepted: 15 October 2021

Published: 30 October 2021

DOI: 10.32996/ijllt.2021.4.10.17

\section{KEYWORDS}

International Relationship,

Translation Studies, Filmology,

Military English, Translation for

Special Purpose(s)

\section{ABSTRACT}

This paper studied 22 influencing Hollywood war films, and extracted translation behaviors among them. Some of the most influencing Hollywood blockbusters themed on wars would be examined to see the role they played in depicting the image of the United States Armed Forces hope to build through the plot(s) of translation activities performed in theatre. From such changes can see the change of people's attention, as well as the effect Hollywood blockbusters contributed on the building of the U.S. Armed Forces' images. Video productions (especially films) are some of the most welcomed ones. The United States has one of the most powerful film-making industries in the world, which successful products of its are popular around the world, definitely have the American way of thinking and judgment spread and accepted by the filmlovers around the world. Research conducted on such films would reveal how the U.S. Armed Forces' image has changed on cinema screens, and provide a collection of data for translation researchers who has an interest in the field combining translation (behaviors) with the mass media.
\end{abstract}

\section{Introduction}

These days, films are getting more and more important in many people's daily lives. Even in the year 2020, the apparent year of a bear market for the global box office thanks to the epidemic caused by the COVID-19 virus, the global figure of box office figures for the top 50 films in 2020 is about 5.4 billion USD (www.163.com, 2021). With this amount of asset 39 F/A-22 "Raptor" planes, one of the most advanced types of the fourth generation fighter could be bought, and that amount would be more than one-fifth of the total amount of the U.S.A.F.'s F/A-22 armada, namely, 196 jets (www.weird.com, 2011).

Films are no longer just, also, made only for people`s entertainment. For many years they have been seen as the carriers of culture: in an average American superhero movie, we would see Caucasian, Latino, African-American, and even Asian-American men and women who dressed in "red, white and blue" uniforms beating evils with their instinctive or later-trained superpowers and even special gadgets. Works like these also indicate the unique style(s) of value(s), ideology(-ies) (and so on) of one or more race(s), region(s) or nation(s) through many aspects, for example, the details of the props, specially-designed plots, dialogues, and themes, etc. Films containing such information would serve as speakers of nations, propagating the information they want to express to their own citizens as well as to the whole world. Such information could be used to support or against certain points-of-views, comfort the mass, create some sort(s) of image(s) in front of the public, etc.

Translation behavior might be very likely to emerge along with the creation of language, with the intention to establish connections between tribes who did not share the same language, make sure they can communicate with their minds instead of bloody swords (Tan, 2018). From this fact, we can realize that translation activity is always a companion of wars and people's pursuit of peace in this world.

This article intends to examine the effect of translation elements hidden in Hollywood war blockbusters depicting the wars included the United States Armed Forces, with an inter-discipline analysis. In this way, may we see the image of the armed forces that the

Copyright: (c) 2021 the Author(s). This article is an open access article distributed under the terms and conditions of the Creative Commons Attribution (CC-BY) 4.0 license (https://creativecommons.org/licenses/by/4.0/). Published by Al-Kindi Centre for Research and Development, London, United Kingdom. 
U.S. intended to show to the whole world? Some of these films were sponsored by the military, others were not, and we might see the differences of the image intended to be made by the military and in civilians` eyes, and the trend of their changes.

\section{Literature Review}

In this section, some of the most important concepts will be examined. This section is designed to help readers to understand the relationship between movies, translation, and international relations.

\subsection{International Relation and the Creation of the Armed Forces' International Images}

Regarding Earth as a small village, its citizens, in other words, all kinds of nations and regions, also live in all corners of it. In a village in the literal sense "relationship" means man's communications, for example, marriage, debt, education, and so on. As nations are seen as actors performing tasks in world affairs, the relation in the Earth Village could be seen as the enlarged version of man's communication in an ordinary village. To be more specific, international relations in this sense means all activities that happened among the 195 nations in this world, including wars, all kinds of leader meetings, negotiations, signing of treaties, and so on (Abidin et al., 2017).

The image of a nation or a certain organization is an icon in the field of international relations (). Videos could offer people the instant impression of certain people, incidents, and even an organization. For example, pictures of Abu Ghraib (Shanker, 2004) were broadcast to the whole world through the television program, the international image of the United States government as a brave and justice War on Terror fighter crashed immediately, and deteriorated into a cold and sick executioner in no time. Modern technology of audio and video facilitate the construction of such images faster than any period of time ever we had experienced.

If an organization of these could last long enough, we may be also lucky enough to see of change in its image in the public's eyes. What could be hidden behind the apparent change on the screens in cinemas and every household's TV? Certainly, there could be historic events like the results of wars, elections, and negotiations between world powers that passively form such images. There could also be deliberate hands that positively create them, like the organizations themselves. The translation of such creation behaviors could help us better understand the reasons behind the change of organizations (actors of international relations), and also the arrangements of props, plots, and all other elements in certain propaganda productions.

\subsection{Modern Film Studies}

Film as a form of art is quite young, in comparison with war and translation, two of man's oldest activities. The earliest film in the world is commonly regarded as La Sortie de l'Usine Lumière à Lyon (Wikipedia, 2014), though Une scène au jardin de Roundhay emerged 7 years earlier (Wikipedia, 2015). From a broad sense, film studies (in other words, "Filmology") includes a broad package of items far more than movies themselves.

Chen (2015) examines film with two approaches, either from the aspect of history or conduct contrastive studies between movies and other works, for example, literature works and plays. Films are seen as crafts carrying cultural information. The author thinks that films can carry information about a specified time, race, or even a nation, etc. The way films carry such information could be varied: the information could be seen by the titles, in the plots, from the dialogues, and could be found even details of the props.

Some organizations deliberately integrate information in films by sponsoring them. Such information could be the image of them, the voice they want to convey to viewers, the effect of such delivery would largely depend on the box office figure of the movies they poured money, equipment, and other resources. For example, the success of TOPGUN (1986) made the U.S. Navy F-14 fighter jet pilot "the coolest job in the world" (www.avclub.com, 2020).

\subsection{Translation Studies and Its Development}

Xie (2003) pointed out that contemporary Western translation studies have experienced "Three Breakthroughs" since the 1950s: at that time, western scholars could already provide well-established tactics and strategies for tackling practical translation questions (Xie, 2001). Scholars then transform their way(s) of translation studies, from simply pursuing word-for-word equivalence between SL and TL to the translation behavior itself, from ST and TT themselves to the procedure of the production and consumption of the translated works, and from viewing translation process an isolated fragment of language transformation to putting it under the scope of cultural context, history, and convention, namely, "cultural turn"(Bassnett \& Lefevere, 1990). There are some iconic scholars who made contributions to these breakthroughs. For example, Roman Jakobson divided translation into three types, intralingual translation, interlingual translation, and intersemiotic translation, extending the examination scope from the narrow sense of SL and TL texts to a much wider field that contains both textual and non-textual information. Also, communications made with the same language could also be seen as the process of translation in Roman Jakobson's eyes, for "there are no different linguistic symbols that are the same, but the information"(Jakobson, 1992). George Steiner considered that when people were 
reading books, participating in dialogues, or even watching movies, we as well as "actors and editors are all translators, for understanding itself is also a type of translation"(Steiner, 1975).

In China, although Dong Qiusi raised the idea that "China should have its own discipline of translation studies" in 1951, such an idea did not raise much attention until the 1980s. What's worse, Chinese giants of translation then, Fu Lei, for example, considered studies that were alienated from practical experience "useless" (Luo, 1984). Therefore, Chinese researchers suffered from the "translated-text-only" constraints for a longer period than their western counterparts. Slowly, by the active movement of Chinese scholars, linguistics methods were, after all, introduced to Chinese translation studies, and it finally embraced its "cultural turn" in the new century (Zhang, 2008). These days, though, Chinese translation studies are still bothered by some classical misconceptions, like "fluent foreign language user could naturally be competent teachers as well as translators" which mix two absolutely distinct notions of "foreign language talents" and "translation research talents"(Wen, 2020), "translation studies must be stuck to practical basis" (Zhang, 2021), etc., more and more Chinese researchers accepted modern methods of translation studies, Chinese translation studies is, therefore, more lined in with global research norms.

Here we could see that Chinese and Western translation studies developed through a similar trend, which researchers' eyes continued to extend wider, from texts-only (ST and TT) to non-textual elements, like codes, translation behaviors, and even the influence caused by the selling and spread of translated works. It is western scholars initialed the change of the translation studies, and Chinese researchers tried to follow up the process. Although Chinese translation studies accept the linguistics breakthrough and the cultural turn breakthrough 10 to 20 years later than their western counterparts, they continue to overcome misconceptions and try to keep up to their pace. Such development allows us to see translation behaviors in these war movies as examine subjects, viewing them from multiple aspects like cultural elements, effects driving the plot forward, the comment of the media, and so on, without being confined by the "SL" and "TL" among the lines.

\section{Methodology}

As is mentioned in the abstract of this article, the author intended to see the role films played in depicting the image of the United States Armed Forces hope to build through the plot(s) of translation activities performed in theatre. To reach this goal, certain films must be viewed, and relative plots contain translation. Films picked for the investigation would have to fulfill several standards:

(1) American-made Hollywood movies, either military-funded/supported or not.

(2) Themes of such movies would be marked as "War", "Action" and "History". Films that themed wars the U.S. Armed Forces had participated in would be mainly taken into consideration.

(3) Movies must be influencing ones, for it is only productions with a certain quality that could attract an audience. Thus the information producers and investors hoped to deliver could be effectively widespread. The selection of "influencing" would follow two standards: box office figure (based on www.boxofficemojo.com) ${ }^{1}$ and authoritative award records (including nominations), for example, the Academy Awards (also called the "Oscar" award). In this sense, both major audiences (ordinary people) and professional viewers could both be considered.

(4) Jakobson considered both the narrow sense of SL-TL transformation as well as communication between two users of the same language and even codes as "translation". In this sense, all the films picked must be reviewed completely from the first moment to their last second, that's hardly practicable. Besides, translation is an important method of communication; no matter on the screen or in reality, it is hard to believe that civilians and counterparts of U.S. troops would take the bullets and airstrikes poured on them as "communicating". Therefore, "translation behaviors" here shall be defined as behaviors undertaken between U.S. troops and non-U.S. troops as well as foreign civilians, in languages including English or other sorts of codes and signals for the purpose of communication. However, some exception(s) would also be presented and explained.

Following the standards above, 22 films were picked as research subjects, namely The Deer Hunter (1978), Apocalypse Now (1979), The First Blood (1982), TOPGUN (1986), Platoon (1986), Full Metal Jacket(1987), The Hunt for Red October (1990), Saving Private Ryan (1998), The Thin Red Line (1998), U-571 (2000), Black Hawk Down (2001), Pearl Harbor (2001), Jarhead (2005), Flags of the Fathers (2006), Hurt Locker (2009), Lone Survivor (2013), American Sniper (2014), Fury (2014), Hacksaw Ridge (2016), Billy Lynn's Long Halftime Walk (2016), 12 Strong (2018) and Midway (2019).

The article would provide data charts as a part of the results/discussion provided and would also offer necessary analysis with approaches not confined to SL/TL texts, but with multiple disciplines like politics, economics, and so on. 


\section{Findings and Discussion}

This section is a comparative or descriptive analysis of the study based on the study results, previous literature, etc. The results should be offered in a logical sequence, given the most important findings first and addressing the stated objectives. The author should deal only with new or important aspects of the results obtained. The relevance of the findings in the context of existing literature or contemporary practice should be addressed.

Table 1. Basic Information of the Movies Selected for the Research

\begin{tabular}{|l|l|l|l|l|}
\hline Year & Name of the Film & War Themed on & $\begin{array}{l}\text { Apparent Translation } \\
\text { Behaviors or Not }\end{array}$ & $\begin{array}{l}\text { Language } \\
\text { Communication }\end{array}$ \\
\hline 1978 & The Deer Hunter & Cold War (Vietnam) & No & - \\
\hline 1979 & Apocalypse Now & Cold War (Vietnam) & No & - \\
\hline 1982 & The First Blood & Cold War (Vietnam) & Yes & English ${ }^{2}$ \\
\hline 1986 & TOPGUN & Cold War (Vietnam) & No & - \\
\hline 1986 & Platoon & Cold War (Vietnam) & No & - \\
\hline 1987 & Full Metal Jacket & Cold War (Vietnam) & Yes & Vietnamese \\
\hline 1990 & The Hunt for Red October & Cold War (Soviet Union) & No ${ }^{3}$ & - \\
\hline 1998 & Saving Private Ryan & WW2 (Europe) & Yes & English, \\
& Grench, \\
\hline 1998 & The Thin Red Line & WW2 (Pacific) & No & - \\
\hline 2000 & U-571 & WW2 (Europe) & Yes & English, German \\
\hline 2001 & Black Hawk Down & Peacekeeping (Somalia) & Yes & English, Somali \\
\hline 2001 & Pearl Harbor & WW2 (Pacific) & No & - \\
\hline 2005 & Jarhead & Invasion (Iraq) & Yes & English, Arabian \\
\hline 2006 & Flags of Our Fathers & WW2 (Pacific) & No & - \\
\hline 2009 & Hurt Locker & War on Terror (Iraq) & Yes & English, Arabian \\
\hline 2013 & Lone Survivor & War on Terror (Afghanistan) & Yes & English, Arabian \\
\hline 2014 & American Sniper & War on Terror (Iraq) & Yes & English, Arabian \\
\hline 2014 & Fury & WW2 (Europe) & Yes & German \\
\hline 2016 & Hacksaw Ridge & WW2 (Pacific) & No & - \\
\hline 2016 & Billy Lynn `s Long Halftime Walk & War on Terror (Iraq) & Yes & English, Arabian \\
\hline 2018 & 12 Strong & War on Terror (Afghanistan) & Yes & English, Uzbek, Arabian \\
\hline 2019 & Midway & WW2 (Pacific) & No & - \\
\hline
\end{tabular}

Table 2. Information of the Translation Participants in the Movies

\begin{tabular}{|c|c|c|c|c|}
\hline Name of the Film & $\begin{array}{l}\text { Role(s) Involved in } \\
\text { Discussion }\end{array}$ & $\begin{array}{l}\text { Rank/Type of Military } \\
\text { Service of the Roles }\end{array}$ & Experiences (Plot) & Languages Involved \\
\hline The Deer Hunter & $\begin{array}{l}\text { Mike Vronsky, Steven } \\
\text { Pushkov, and Nick } \\
\text { Chevotarevich }\end{array}$ & $\begin{array}{l}\text { Enlisted men of the } \\
\text { U.S.Army }\end{array}$ & $\begin{array}{l}\text { Being captured and } \\
\text { tried to escape from a } \\
\text { Vietnamese POW } \\
\text { camp. }\end{array}$ & None \\
\hline Apocalypse Now & $\begin{array}{l}\text { Colonel Walter Kurtz } \\
\text { Lieut.Colonel William } \\
\text { "Bill" Kilgore, etc. }\end{array}$ & $\begin{array}{l}\text { (Ex-)U.S. Army officers, } \\
\text { etc. }\end{array}$ & $\begin{array}{l}\text { Kilgore's experience of } \\
\text { the mission of } \\
\text { assassinating ex- } \\
\text { colonel Kurtz, who } \\
\text { started his own empire } \\
\text { in Vietnam. }\end{array}$ & None \\
\hline The First Blood 5 & $\begin{array}{l}\text { John J. Rambo, Sheriff } \\
\text { William "Will" Teasle, } \\
\text { and Deputy Sergeant } \\
\text { Arthur "Art" Galt }\end{array}$ & $\begin{array}{l}\text { Enlisted man of the U.S. } \\
\text { Army Special Forces } \\
\text { ("Green Berets") }\end{array}$ & $\begin{array}{l}\text { Vietnam War veteran } \\
\text { Rambo suffered from } \\
\text { discrimination and } \\
\text { torture for no reason } \\
\text { by the police and } \\
\text { conducted his self- } \\
\text { defense then. }\end{array}$ & $\begin{array}{l}\text { English(Intralingual } \\
\text { and Intersemiotic } \\
\text { Translation) }\end{array}$ \\
\hline
\end{tabular}




\begin{tabular}{|c|c|c|c|c|}
\hline TOPGUN & $\begin{array}{l}\text { Pete "Maverick" } \\
\text { Mitchell }\end{array}$ & $\begin{array}{l}\text { (Officer) Lieutenant of } \\
\text { the U.S. Navy (fighter } \\
\text { pilot) }\end{array}$ & $\begin{array}{l}\text { The experience of } \\
\text { training and real-war } \\
\text { of Maverick as an F-14 } \\
\text { elite pilot. }\end{array}$ & None \\
\hline Platoon $^{6}$ & $\begin{array}{l}\text { Soldiers of B Company, } \\
25^{\text {th }} \text { Infantry Division }\end{array}$ & $\begin{array}{l}\text { Officers, sergeants, and } \\
\text { enlisted men of the U.S. } \\
\text { Army }\end{array}$ & $\begin{array}{l}\text { The story of Chris } \\
\text { Taylor, a university } \\
\text { dropout's volunteer } \\
\text { experience in the } \\
\text { Vietnam War. }\end{array}$ & None \\
\hline Full Metal Jacket & $\begin{array}{l}\text { A Marine Corps which } \\
\text { Unit Code is not given }\end{array}$ & $\begin{array}{l}\text { Enlisted men of the } \\
\text { USMC }\end{array}$ & $\begin{array}{l}\text { Fighting against North } \\
\text { Vietnamese soldiers. }\end{array}$ & $\begin{array}{l}\text { English-Vietnamese } \\
\text { (Interpretation) }\end{array}$ \\
\hline $\begin{array}{l}\text { The Hunt for Red } \\
\text { October }\end{array}$ & $\begin{array}{l}\text { The crew of Soviet } \\
\text { Submarine } \\
\text { October and USS Dallas }\end{array}$ & $\begin{array}{l}\text { (Officer) Captain 1st } \\
\text { rank Marko Ramius, } \\
\text { commander of the Red } \\
\text { October } \\
\text { (Officer) Commander } \\
\text { Bart Mancuso, } \\
\text { commander of USS } \\
\text { Dallas } \\
\text { (CIA expert) Jack Ryan } \\
\text { and their crew, etc. }\end{array}$ & $\begin{array}{l}\text { The story of a group of } \\
\text { Soviet rebellion troops } \\
\text { trying to surrender } \\
\text { themselves and the } \\
\text { most advanced Soviet } \\
\text { Red October submarine } \\
\text { to the U.S. Navy. }\end{array}$ & None \\
\hline Saving Private Ryan & $\begin{array}{l}\text { A Ranger rescue team } \\
\text { led by Captain John } \\
\text { H.Miller }\end{array}$ & $\begin{array}{l}\text { (NCO) Corporal of U.S. } \\
\text { Army Rangers } \\
\text { (Timothy) } \\
\text { (Officer) Captain of U.S. } \\
\text { Army Rangers (Miller), } \\
\text { etc. }\end{array}$ & $\begin{array}{l}\text { The story of an elite } \\
\text { troop sacrificed } \\
\text { themselves in order to } \\
\text { save the remained son } \\
\text { of the Ryan family. }\end{array}$ & $\begin{array}{l}\text { English-French } \\
\text { English-German } \\
\text { English (Sight } \\
\text { Intralingual } \\
\text { Translation) }\end{array}$ \\
\hline The Thin Red Line & $\begin{array}{l}\text { A company belongs to } \\
\text { the } 25 \text { Infantry Division }\end{array}$ & $\begin{array}{l}(\mathrm{NCO}) \quad 1^{\text {st }} \text { Sergeant } \\
\text { Edward Welsh, etc. }\end{array}$ & $\begin{array}{l}\text { The story happened to } \\
\text { the C Company during } \\
\text { the Battle of } \\
\text { Guadalcanal. }\end{array}$ & None \\
\hline U-571 & $\begin{array}{l}\text { Commander of the U- } \\
\text { boat, the crew of U.S. } \\
\text { submarine S-33 }\end{array}$ & $\begin{array}{l}\text { (Officer) Lieutenant } \\
\text { Michael Hirsch of U.S. } \\
\text { Navy } \\
\text { (Enlisted man) Seaman } \\
\text { Bill Wentz of U.S. Navy, } \\
\text { etc. }\end{array}$ & $\begin{array}{l}\text { The fictional story of } \\
\text { American submarine } \\
\text { S-33 camouflaged as } \\
\text { German resupply U- } \\
\text { boat to capture U-571, } \\
\text { a German U-boat } \\
\text { deteriorating allies' } \\
\text { ocean supply lines. }\end{array}$ & English-German \\
\hline Black Hawk Down & $\begin{array}{l}\text { Elite U.S. troops } \\
\text { including Delta Force, } \\
\text { Rangers, } 160^{\text {th }} \text { SOAR, } \\
\text { etc. }\end{array}$ & $\begin{array}{l}\text { (NCO) Sergeant First } \\
\text { Class Norm "Hoot" } \\
\text { Gibson (Delta Force) } \\
\text { (NCO) Staff Sergeant } \\
\text { Matt Eversmann } \\
\text { (Rangers) } \\
\text { Chief Warrant Officers } \\
\text { piloting helicopters of } \\
\text { the U.S. Army } \\
\text { A local warlord who } \\
\text { speaks English }\end{array}$ & $\begin{array}{l}\text { U.S. special troops lost } \\
\text { two Blackhawk } \\
\text { helicopters while } \\
\text { capturing local warlord } \\
\text { Mohamed Farrah } \\
\text { Aidid. A fast-capture } \\
\text { mission then turned } \\
\text { into a desperate } \\
\text { defense mission } \\
\text { allowing "no one be } \\
\text { left behind." }\end{array}$ & English-Arabian \\
\hline Pearl Harbor & $\begin{array}{l}\text { Rafe McCawley and } \\
\text { Danny Walker }\end{array}$ & $\begin{array}{l}\text { (Officer) } 1^{\text {st }} \text { Lieutenants } \\
\text { of the USAAF. }\end{array}$ & $\begin{array}{l}\text { (1)Defended Pear } \\
\text { Harbor by fighters. } \\
\text { (2) Bombed Tokyo with } \\
\text { Doolittle. }\end{array}$ & None \\
\hline Jarhead $^{8}$ & Anthony Swofford & $\begin{array}{lll}\text { Sniper of the } \\
\text { U.S.Marine Corps }\end{array}$ & $\begin{array}{l}\text { The experience of } \\
\text { Swofford as a teenager }\end{array}$ & English-Arabian \\
\hline
\end{tabular}




\begin{tabular}{|c|c|c|c|c|}
\hline & & & $\begin{array}{l}\text { in a failed family, his } \\
\text { experience as a trainee } \\
\text { on Parris Island, and his } \\
\text { war experience during } \\
\text { Operation Desert } \\
\text { Shield. }\end{array}$ & \\
\hline Flags of Our Fathers & $\begin{array}{l}\text { Pharmacist's Mate } \\
\text { Second Class John } \\
\text { Bradley, Corporal Rene } \\
\text { Gagnon, etc }\end{array}$ & $\begin{array}{l}\text { (Enlisted } \\
\text { man)Pharmacist's Mate } \\
\text { Second Class of U.S. } \\
\text { Navy } \\
\text { (NCO)Corporal of } \\
\text { USMC, etc }\end{array}$ & $\begin{array}{l}\text { The story behind the } \\
\text { historic flag-raising } \\
\text { picture during the } \\
\text { battle of Iwo Jima. }\end{array}$ & None \\
\hline Hurt Locker & $\begin{array}{l}\text { Lieut.Colonel John } \\
\text { Cambridge, Sergeant } \\
\text { First Class William } \\
\text { James, and his EOD } \\
\text { team }\end{array}$ & $\begin{array}{l}\text { Officers and NCOs of } \\
\text { the U.S. Army }\end{array}$ & $\begin{array}{l}\text { The story of a team of } \\
\text { EOD troops and their } \\
\text { Iraqi war experience. }\end{array}$ & English-Arabian \\
\hline Lone Survivor & $\begin{array}{l}\text { A 4-man navy SEAL } \\
\text { team led by Lieutenant } \\
\text { Michael Murphy }\end{array}$ & $\begin{array}{l}\text { American elite troops } \\
\text { including navy SEALs, } \\
\text { Rangers, etc. }\end{array}$ & $\begin{array}{l}\text { Story of the Operation } \\
\text { Red Wings. }\end{array}$ & English-Arabian ${ }^{9}$ \\
\hline American Sniper & $\begin{array}{l}\text { Experience of navy } \\
\text { SEAL sniper Chris Kyle }\end{array}$ & $\begin{array}{l}\text { (Officer) Chief Warrant } \\
\text { Officer }\end{array}$ & $\begin{array}{l}\text { Early life and combat } \\
\text { experience of } \\
\text { American's deadliest } \\
\text { sniper Kris Kyle. }\end{array}$ & English-Arabian \\
\hline Fury & $\begin{array}{l}\text { A Sherman tank crew } \\
\text { led by Staff Sergeant } \\
\text { Don } \\
\text { Collier }\end{array}$ & $\begin{array}{l}\text { (NCO)Staff Sergeant of } \\
\text { U.S. Army }\end{array}$ & $\begin{array}{l}\text { Capture a town with } \\
\text { infantry, and defend a } \\
\text { cross against a whole } \\
\text { SS battalion with a } \\
\text { single tank. }\end{array}$ & English-German \\
\hline Hacksaw Ridge & $\begin{array}{l}\text { Corporal Desmond } \\
\text { Doss and his fellows }\end{array}$ & $\begin{array}{l}\text { (NCO) Corporal of U.S. } \\
\text { Army }\end{array}$ & $\begin{array}{l}\text { Biographic film of } \\
\text { Doss's experience as a } \\
\text { medic during WW2. }\end{array}$ & None \\
\hline $\begin{array}{l}\text { Billy Lynn`s Long } \\
\text { Halftime Walk }\end{array}$ & $\begin{array}{l}\text { Private Billie Lynn and } \\
\text { the squadron he } \\
\text { belongs to }\end{array}$ & $\begin{array}{l}\text { (NCO) Specialist Billie } \\
\text { Lynn, etc. }\end{array}$ & $\begin{array}{l}\text { Billie Lynn`s experience } \\
\text { of attending a football } \\
\text { game as a war hero } \\
\text { and his sad memories } \\
\text { of war. }\end{array}$ & English-Arabian \\
\hline 12 Strong & $\begin{array}{l}\text { ODA-595 team led by } \\
\text { Captain Mitch Nelson }\end{array}$ & $\begin{array}{l}\text { An ODA team of the } \\
\text { Green Berets. }\end{array}$ & $\begin{array}{l}\text { ODA-595 was sent to } \\
\text { Afghanistan as } \\
\text { America`s revenge } \\
\text { attack towards the } \\
\text { Taliban after the } 9 / 11 \\
\text { event. }\end{array}$ & $\begin{array}{l}\text { English-Uzbek } \\
\text { English-Arabian }\end{array}$ \\
\hline Midway & $\begin{array}{l}\text { Lieutenant Dick Best } \\
\text { Lieutenant } \\
\text { Commander Wade } \\
\text { Maclusky, etc. }\end{array}$ & $\begin{array}{l}\text { (Officer) Dive bomber } \\
\text { pilots and torpedo } \\
\text { attacker pilots of WW2 } \\
\text { U.S. aircraft carriers }\end{array}$ & $\begin{array}{l}\text { Battle of Midway } \\
\text { between the US and } \\
\text { Japan during WW2. }\end{array}$ & None \\
\hline
\end{tabular}


Table 3. Detailed Translation Records of the Films in Table 2.

\begin{tabular}{|c|c|c|}
\hline Name of the Film & 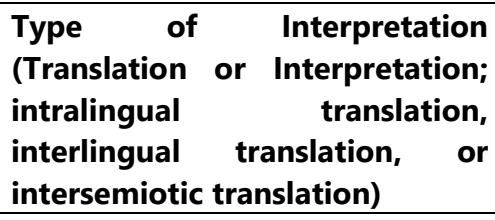 & Detailed Translation Behaviors \\
\hline The First Blood & $\begin{array}{l}\text { English(Intralingual } \\
\text { Intersemiotic Translation) }\end{array}$ & $\begin{array}{l}\text { (1)Intralingual Translation: Sheriff Teasle did not believe } \\
\text { in Rambo's explain after seeing the body of Sergeant } \\
\text { Gore, and thus determined Rambo as the murder. } \\
\text { (2)Intersemiotic Translation: Rambo's army jacket was } \\
\text { identified and being recognized as "unwelcome" by the } \\
\text { sheriff; Gore's abusive acts reminded Rambo of his } \\
\text { unhappy memory as a captive in Vietnam. }\end{array}$ \\
\hline Full Metal Jacket & $\begin{array}{l}\text { English-Vietnamese } \\
\text { (Interpretation) }\end{array}$ & $\begin{array}{l}\text { A group of USMC soldiers called a Vietnamese hook, } \\
\text { the procuress (an ARVN soldier) worked as the } \\
\text { interpreter. }\end{array}$ \\
\hline Saving Private Ryan & $\begin{array}{l}\text { English-French } \\
\text { English-German } \\
\text { (Interpretation) } \\
\text { English (Sight Intralingual } \\
\text { Translation) }\end{array}$ & $\begin{array}{l}\text { (1) Corporal Timothy was chosen as Captain Miller (he } \\
\text { also understands German)'s French and German } \\
\text { interpreter, using French to communicate with a } \\
\text { French family about the motions of the German forces } \\
\text { nearby, and tried his best to comfort them. } \\
\text { (2) Captain Miller interrogated a surrendered German } \\
\text { POW with the support of Corporal Timothy but set him } \\
\text { free instead of having him shot. } \\
\text { (3) While searching for Private Ryan, the crew met a } \\
\text { paratrooper whose ears were badly damaged, so they } \\
\text { wrote words on a piece of paper to ask him questions } \\
\text { and Captain Miller ordered his man to write "Thank you" } \\
\text { to him. }\end{array}$ \\
\hline$U-571$ & $\begin{array}{l}\text { English-German } \\
\text { (Interpretation) }\end{array}$ & $\begin{array}{l}\text { Lieutenant Michael Hirsch with his German ability } \\
\text { successfully pretended to be a German resupply } \\
\text { officer. With fluent German he convinced and thus } \\
\text { distracted German submarine officers, thus American } \\
\text { sailors successfully captured the Kreigsmarine U-571. }\end{array}$ \\
\hline Black Hawk Down & $\begin{array}{l}\text { English-Somali } \\
\text { (Interpretation and Intersemiotic } \\
\text { Translation ) }\end{array}$ & $\begin{array}{l}\text { (1)Intralingual Translation: SGT Ed Yurek was once lost } \\
\text { and couldn't find other fellows. He was pursued by a } \\
\text { gang of militia and bumped into a civilian's flat to save } \\
\text { his life. He seemed not to know Somali or Arabian, but } \\
\text { with his gestures, he successfully calmed the owner of } \\
\text { the flat down, and thus escaped from the militia. } \\
\text { (2)Interpretation: Sergeant First Class Norm "Hoot" } \\
\text { Gibson went to the second Blackhawk helicopter, he } \\
\text { and his fellows uttered Arabian to drive the mobs } \\
\text { looting the helicopter away, and distracted the } \\
\text { militia in order to capture their canon. } \\
\text { (3) A Lieutenant of Aidid used English to communicate } \\
\text { with the captive American helicopter pilot. }\end{array}$ \\
\hline Jarhead & $\begin{array}{l}\text { English-Arabian } \\
\text { (Interpretation) }\end{array}$ & $\begin{array}{l}\text { (1) Swofford drove the nomadic tribe away from his } \\
\text { troop with the Arabian. }\end{array}$ \\
\hline Hurt Locker & $\begin{array}{l}\text { English-Arabian } \\
\text { (Interpretation) }\end{array}$ & $\begin{array}{l}\text { (1)Lt.Colonel Cambridge tried using a few Arabian } \\
\text { words communicating with terrorists pretended to be } \\
\text { residents of the street where a bomb was discovered } \\
\text { and was killed for the terrorists detonated the bomb. } \\
\text { (2) James encountered a little boy named Beckham } \\
\text { selling pirate DVDs and played football with him. The } \\
\text { kid spoke English instead of Arabian to him. Later }\end{array}$ \\
\hline
\end{tabular}




\begin{tabular}{|c|c|c|}
\hline & & $\begin{array}{l}\text { when James sneaked out of the base in search of a } \\
\text { terrorist, he broke into a local professor's home and } \\
\text { talked to him in English. } \\
\text { (3) James would use the Iraqi soldiers on the scene as his } \\
\text { Arabian interpreter to help deal with the crowd or give } \\
\text { instructions to certain people(hostages or suspects). } \\
\text { It also seemed that James understands Arabian himself } \\
\text { to a certain degree. }\end{array}$ \\
\hline Lone Survivor & Intersemiotic Translation & $\begin{array}{l}\text { Facing the Afghani friendly locals, Marcus Luttrell did } \\
\text { not know whether he should trust them since he and his } \\
\text { crew were betrayed once. The locals uttered to comfort } \\
\text { him, but he did not understand their language. After all, } \\
\text { he believed that the locals meant no harm (perhaps } \\
\text { he was then exhausted, too) through their body } \\
\text { language and expressions. }\end{array}$ \\
\hline American Sniper & $\begin{array}{l}\text { English-Arabian } \\
\text { (Interpretation) }\end{array}$ & $\begin{array}{l}\text { (1)The sniper team in the film, along with other US } \\
\text { ground forces, employs the Iraqi police force as their } \\
\text { Arabian interpreters. However, they only } \\
\text { interpreted the language literally, and for some time } \\
\text { almost got the US troops killed (the resident's US } \\
\text { troops questioned were pretended by terrorists). }\end{array}$ \\
\hline Fury & $\begin{array}{l}\text { English-German } \\
\text { (Interpretation) }\end{array}$ & $\begin{array}{l}\text { (1)To acquire intelligence from German people who } \\
\text { were friendly to US troops (an old man walking on the } \\
\text { street, a surrendered teacher who did not want to work } \\
\text { for the Waffen SS, etc). } \\
\text { (2)To interrogate German POWs. }\end{array}$ \\
\hline Billy Lynn`s Long Halftime Walk & $\begin{array}{l}\text { English-Arabian } \\
\text { (Interpretation) }\end{array}$ & $\begin{array}{l}\text { Billie Lynn`s squadron was ordered to search a house, } \\
\text { Lynn`s squadron leader asked a few questions with the } \\
\text { local police force as the interpreter. However, the } \\
\text { interpreter did not fully fulfill his task. Although the } \\
\text { owner denied he had a connection with Saddam } \\
\text { Hussein, he was later confirmed by the soldiers } \\
\text { themselves as ex-colonel in Hussein's army, and } \\
\text { weapons were found in his residence. None of the } \\
\text { soldiers in Lynn's squadron seemed to understand } \\
\text { Arabian. }\end{array}$ \\
\hline 12 Strong & $\begin{array}{l}\text { English-Uzbek } \\
\text { English-Arabian } \\
\text { (Interpretation) } \\
\text { Intersemiotic Translation }\end{array}$ & $\begin{array}{l}\text { (1)English-Uzbek: By exchanging conventional } \\
\text { greetings in Uzbek (also interpret for his fellows), } \\
\text { Captain Mitch successfully broke the ice with General } \\
\text { Dostum (local warlord) for his team in order to jointly } \\
\text { strike the Taliban. } \\
\text { (2)English-Arabian: Green Berets who understand } \\
\text { Arabian naturally serve as combat coordinators for } \\
\text { their fellows as well as the warlord's armed forces. } \\
\text { (3)Intersemiotic Translation: though some Green Berets } \\
\text { who spoke neither Uzbek nor Arabian, they either } \\
\text { employ a local interpreter to acquire information } \\
\text { and resources, or build friendly bonds with the } \\
\text { warlord's forces. For example, an African-American } \\
\text { Green Beret offered gifts and friendly gestures to a } \\
\text { teenager local soldier, and his kindness was well- } \\
\text { received. }\end{array}$ \\
\hline
\end{tabular}




\section{Findings}

Based on the results found in the third section, several findings would be presented below:

\subsection{Producers are emphasizing more on war films` translation behaviors}

Starting from the very first record (the year 1978), to the end of the Cold War (the year 1991 when the Soviet Union fell), there were 13 years. Among Table 1., there were 7 influencing war films, 3 of them contained translation behaviors in plots (about 42.857\%). In another 13 years (1992-2005), there were 6, of which 4 of them contained such plots (about 66.667\%). Between the years 2006 and 2019, the figure turned out to be 6 in 9. Therefore, it's obvious that producers are steadily adding more such plots in the films. Almost all translation behaviors were conducted in the form of interpretation. Most interpreters are elite troop members or troop leaders ${ }^{11}$.

Besides, the intention of employing translation behaviors also quietly changed. According to Table 3., Translation behaviors that war films contained during the Cold War carried negative even sick intentions of U.S. troops. Films depicting the Vietnam War tried their best to perform the bloody (in other words, cruel) side of war. Even the seemingly "peaceful" translation behaviors were used to highlight such features. For example, the dialogue between Rambo and Sheriff at the cliff only exacerbated the conflict that could at first be avoided had him allow Rambo "having something to eat". And the marines would only need an interpreter under the circumstance of finding a whore to "relax" themselves. In a word, American soldiers are murderers and bandits in these films. They would only add more pain and death to the locals no matter what they do. Whereas in the later films, scenes of translations turned out to be much milder. With the help of an interpreter, soldiers could try their best to comfort civilians horrified by gunfire and broken limbs flying around, they could cooperate skilfully with the local "freedom fighters" confirmed by the U.S. government, and even grow a solid bond with the locals. Although local interpreters are under most circumstances undependable, the U.S. troops would still choose to believe them unconditionally in the first place.

\subsection{The Shift of Public Attention}

From these 22 picked films, it seems that three stages could be concluded ${ }^{10}$ :

Stage One (1977-1990): The first half of this phase sees the fail of the Vietnam War and the impact of stagflation laid heavy strike on American People's morale and wallet. And since the morale-strike was at the same time a money-burner, American people would definitely see the military as a tool to vent their anger. But in the latter half of this period, President Reagan steadily made progress in recovering the American economy, while the military gained several important victories during the presidency of President George Bush senior, which restored part of the people's confidence. On the other hand, the Soviet Union was continued to decay after the death of Brezhnev; American people thus convinced that they would, at last, overcome their counterpart, so they regained their confidence and love to their own troops since the crucial fall happened in the Vietnam War. During the later part of this period, films sponsored by the armed forces successfully portrayed a heroic image among the viewers home and abroad; not every one of them contained translation plots, but in the viewers' eyes being a soldier is very likely equivalent to a welcoming adventure story which also embraced fortune and romance.

Stage Two (1991-2009/2011): Before and in the first years after the War on Terror the U.S. Armed Forces suffered some failures, and American people began to consider lessons they'd learned in these local wars. Soldiers on the screen in this period is milder than the last period; they would kill anyone they met with anger and curse, they would stop and observe, trying their best to avoid the abusive use of the force. Such films expressed the side of the weakness and humanity of soldiers who 're often viewed as "killing machines", and called for people's sympathy towards them. Translation behaviors in the scenes would show the kind side of these men, showing that sometimes the use of force is their last choice after a heavy sacrifice, thus facilitating people's positive views on the military.

Stage Three (2012-recent times): As the situation of War on Terror continues to deteriorate, with an apparent scene of the fall of Afghanistan, along with other dangerous disasters as well as failed bail-out policies undertaken by the White House, it seems that people's trust to their government and troops is again on the edge of crashing down. Then producers were trying to awaken the fire of heroism in viewers' hearts. Role models like Chris Kyle and Marcus Luttrell were erected on the screen. And more WW2 films were made as if these producers are reminding people of the achievements the United States has done to the world with the flower of its lads. Translation Behaviors in these films helped to create a fuller image of these heroes: they were kind, considerate, willing to understand the locals through peaceful communication, and the United States tends to send the best of these communicators to the battlefield.

Despite all this kind of information that may be contained, we still need to realize that most of the translation activities were conducted to facilitate combat actions, which means, to better fight against the enemies of the United States. However, we may never know what really happened in the battlefields of Iraq, Afghanistan, and other places where the U.S.Armed Forces might show 
up, but they did perform less bloody than what they have done on the screen in the 1980s through the communication with other troops and civilians through translation behaviors.

It is also noteworthy that most translation activities in films that were mentioned above were both setting English as TL. It might show that the United States is the power that dominates the situation of the battlefield, but could also be an indicator showing the dominance of English as a world Lingua Franca (Liang \& Yang, 2020).

Last but not least, judging from the fact that almost all films contained no translation behavior towards Japanese troops in WW2, circumstantial evidence of the deduction that American people displayed more respect to the German troops in WW2, while the Japanese troops were mocked and criticized as maniacs and barbarians could be provided ${ }^{12}$.

\section{Conclusion: The Shift of Image of U.S.Armed Forces Created by Hollywood Blockbusters}

Based on the former part of this article, we have seen that the image of the U.S.Armed Forces had changed vastly according to the available data collected and analyzed since the year 1977. We have seen that the hard, bloody, and disgusting image of the U.S. troops is becoming milder and greater with the help of translation plots which showed up more and more in the films, making the troops' image seems nicer and more helpful in the combat zone to viewers home and abroad. Besides, translation plots also seemed to highlight the dominance of English as an international language and American people's traditional prejudice towards certain nations.

The major limitation of this research lies in the selection of its research subjects: the data contained in the website does not contain information on renowned films before the year 1977, and some films which may be important to this topic but are not influencing are not included. For other researchers, it would be very helpful for them to gather and study the material mentioned before in order to dig further in this field.

Funding: This research received no external funding.

Acknowledgments: The initial creativity was inspired by Professor Han Ziman of Shanghai International Studies University. The writing process and the revision were all undertaken by the author himself, but he would like to extend his sincere gratitude to Dr. $\mathrm{Li}$ Zhaofei, lecturer of the graduate students program of International Relations lecture, who inspired the author to undertake further research and provide him with effective suggestions and directions.

\section{Note:}

1. The earliest record the website holds is of the year 1977`s.

2. As a matter of fact, Rambo's enemy is the police department of a quiet American little town. The biggest conflict here is the Sheriff's interpretation of Rambo, he refused to regard him equally but tried to get rid of him at all costs, even condoning his lieutenants to abuse him. See the author's detailed explanation in the fourth section.

3. Both the Red Navy and the U.S. Navy spoke English in this film. It seems that language problems had been ignored by the producers.

4. Neither Iraq nor Afghanistan is a sole-language nation, what language people would speak depend on the language the tribes they live in use. Persian, Arabian Kurdish, and English (for general purposes) could be heard in Iraq, while the Pushtu language and Dari could be heard in Afghanistan. In the films mentioned above all enemies, the U.S. Armed Forces encountered used Arabian. In fact, there are even more languages that could be heard there had the Al Qaeda terrorists from other places been taken into consideration. The initial dialogue between Captain Mickey Nelson (leader of the ODA 595 team) and General Dostum (Afghanistan local warlord) was conducted by Uzbek. Later when the U.S. special troops gained the trust of the general, he began to talk to them in English.

5. The First Blood is also a series containing 5 movies of different stories, the initial work we discussed here was produced based on David Morrell's novel Rambo (1972), in which Rambo committed suicide at last. However, this end was revised because viewers considered it "too depressed". Because of the first film's success, the rest of the 4 movies was then produced in half a century, and David Morrell novelized the second and third film of the Rambo series, despite the end in his first original work. Among the series, the first and the second were the most influencing ones. However, we would not include the second one here as it was completely fictional and is totally right-wing propaganda that claimed that Americans can win (although they in fact did not win) the Vietnam War (www.empireonline.com, 2006).

6. In fact, an American sergeant did use Vietnamese shouting at the farmers hiding in a hole covered by forage, forcing them to come out. This article did not take it into consideration, because the sergeant did not holler to communicate, but to have them gathered and murdered. Even if the farmers refused to come out, they would also be killed by a flamethrower or a grenade.

7. The Ryan family has 5 sons, they sent them all the U.S. troops fighting the Second World War, and four of them died on the day of 6 June 1944. The military considered it necessary to save the remained Ryan at all cost. 
8. Jarhead was later developed into a series of movies. However, the rest of the movies have no connection with the first one and did not have the influence as big as the first one. Therefore, Jarhead 2: Field of Fire (2014), Jarhead 3: The Siege (2016), and Jarhead: Law of Return (2019) would be included in this research. As for Mr. Swofford's rank, he was at first an NCO (corporal) of the Marine Scout Sniper, an elite troop of USMC, but was later demoted to private because he drank illegal alcohol and burned part of the barracks under extreme anxiety.

9. In the film 's latter part in fact the communication was "failed" from a narrow sense, since Marcus Luttrell did not understand the local's language, and the locals did not get English, either. However, Marcus Luttrell somehow found out that the locals meant no harm to him, and accepted their help instead of pulling out the grenade pin to kill himself.

10. Such a conclusion has its limitation of confined data figure, it could possibly be renewed had more data available.

11. Troop leaders do not have to be an officer, see PLA ex-Colonel Li Donglei's explain on the NCO system of the U.S.Armed Forces and its differences in comparison with China's PLA (Li, 2009).

So far no direct official statements had been seen on this point of view, but influencing TV series and films always show such a tendency. See the difference in how German and Japanese surrendered troops were received by the Americans in HBO mini-series Band of Brothers (Part 10) and Pacific (Part 9), two of the most highly-valued WW2 TV plays.

Conflicts of Interest: The author declares no conflict of interest.

\section{References}

[1] Abidin, S.Z. (2017). International Relations. Bristol: E-International Relations Publishing.

[2] Bassnett, S. \& Lefevere, A. (eds.) (1990), Translation, History, and Culture. London: Pinter.

[3] Chen, X.Y. (2015) Dianyingxue Daolun [Filmology]. Beijing: Beijing United Publishing Co., Ltd.

[4] Jakobson, R. (1992). On linguistic aspects of translation - An anthology of essays from Dryden to Derrida [A] In Rainer Schulte and John Biguenet (ed.). Theories of Translation. Chicago: The University of Chicago Press.

[5] Hansen, L. (2015). How images make world politics: International icons and the case of Abu Ghraib. Review of International Studies, 41(2), 263-288.

[6] Luo, X.G. (1984). Traduction. Beijing: The Commercial Press.

[7] Steiner, G (1975). After Babel — Aspects of Language and Translation. London: Oxford University Press.

[8] Tan, Z.X. (2018). A Short History of Translation in the West.Beijing: The Commercial Press.

[9] Li, D.L. (2009). Yige Tuiyi Zhongxiao De Meijun Yinxiang [A Retired PLA Lt.Colonel's Impression on the United States Armed Forces]. Bingqi Zhishi B: Fangwu Guanchajia [Ordnance Knowledge B: Observer]. (261):61-65.

[10] Liang, L.Q. \& Yang, Q. (2020). On the Role of Translators and Interpreters in Multicultural Context. Journal of Kaifeng Vocational College of Culture \& Art,2020,40(12):53-56.

[11] Wen, M.F. (2020). The Current Situation of MIT Teaching and Cultivation of Inter-Disciplinary Translation Talents in China. Xibu Wenxian Bianyi Yanjiu Zhongxin[Sichuan Western Literature Compilation and Research Center]. (eds.) Innovative Research on Foreign Language Education and Translation Development (10 (pp. 518-521).

[12] Xie, T.Z. (2001). On the Misconceptions in Translation Studies and Theories in Our Country. Chinese Translators Journal. 22(4), 02-05.

[13] Xie, T.Z. (2003). Three breakthroughs \& two turns in contemporary Western Translation Studies. Journal of Sichuan International Studies University. 15(5), 110-116.

[14] Zhang Y. Evolution and Conflicts: Investigation of China`s Translation Studies from 1979 to 2007. 2008. Shanghai International Studies University, Ph.D. dissertation.

[15] Zhang, Y.X. (2021). On the Evaluation and Innovation of "Translated Text Studies": Also discuss with Associate Professor Geng Qiang. Journal of North China University of Technology(01),110-115. DOI : CNKI : SUN:BFGY.0.2021-01-017. 